\title{
REGULATION OF BEHAVIORAL DEVIATIONS IN THE YOUTH ENVIRONMENT
}

\author{
ROKSOLIANA ZOZULIAK-SLUCHYK
}

\begin{abstract}
The problem of regulation of behavioral deviations in the youth environment attracts the attention of many researchers in various branches of science. Regulation of behavioral deviations means the prevention of unfavorable living conditions of adolescents, namely the elimination of factors that can cause certain negative consequences. The article reveals and analyzes the important factors that determine the criminal behavior of adolescents. In particular, such factors are singled out: uncensored propaganda of negative behavior styles that provoke adolescents to imitate «heroes» with bloody and violent behavior; the influence of families that give their children little attention from preschool age, turn a blind eye to their bad behavior, have an irresponsible attitude to the world around them and the environment, encourage their children's whims; inconsistency of legal reform, extremes in modern judicial practice. The results of the study of predisposition to criminal behavior of adolescents are also presented. The methods chosen for the study: "Diagnosis of the tendency to overcome social norms and rules (Yu.A. Kleiberg)", "Methods of diagnosing the tendency to deviant behavior (A.N. Orel)", "Diagnosis of hostility (according to the Cook-Medley scale)", "Obozov-Shchokintest to determine the degree of determination", "A. Bass-A. Dark diagnosis of indicators and forms of aggression". The type of social regulation of behavioral deviations such as individual prevention of juvenile delinquency is considered in detail. Its essence is purposeful work with a particular teenager and their closest people. Social workers, social educators and modern law enforcement agencies are comprehensively called to carry out this type. Individual prevention is directed at the adolescent and their negative traits, the environment that shapes them, as well as the conditions, circumstances and situations that contribute to or facilitate the commission of crimes by minors.
\end{abstract}

Keywords: regulation of behavioral deviations, youth environment, adolescent, prevention, deviant behavior, crime.

\section{INTRODUCTION}

The current situation at the current stage of Ukraine's formation has determined the social, economic and political processes of the country's development. Globalization processes have led to new opportunities and new problems for the establishment of Ukrainian youth. Present challenges and problems are caused by various degrees of risk to human security, which did not exist before. These include unemployment, poverty and property inequality, deteriorating quality of life, access to basic social benefits, to education and health, caused by the war, decline of family values, which leads to a sharp spread of behavioral deviations, in particular: alcohol and drug use, the spread of HIV / AIDS, juvenile delinquency in the youth environment. 
The negative factors that require finding ways to create a safe social environment which would counter these trends, would promote creation of new opportunities for young people, which should be provided by a modern democratic society are outlined.

Undoubtedly, juvenile delinquency is dominant today among behavioral deviations. Juvenile delinquency is a social evil and a serious challenge to society. Therefore, the prevention of juvenile delinquency is, in our opinion, a priority task for social work specialists.

\section{THEORETICAL BACKGROUND}

Considering the problem of juvenile delinquency, as representatives of today's youth environment, in our opinion, we can identify a set of key factors that contribute to its growth. Among them, the main one is the family, which contributes to the upbringing of future criminals. After all, there are a large number of families in which children are given little attention from preschool age, family members turn a blind eye to their bad behavior, irresponsible attitude to the world around them and the environment, encourage their whims, which contributes to the formation of bad habits. The combination of all these negative features later becomes a lifestyle that can lead a person to a crime. Another factor is the uncensored propaganda of negative behaviors that provoke adolescents to imitate "heroes" with bloody and violent behavior and so on. The implementation of which in the life of a teenager with a lack of moral core values also does not contribute to positive socialization. The pursuit of fulfilling of vital needs among young people causes the desire to make a profit in any way, including a criminal one.

Among the factors of a legal nature that cause behavioral deviations, first of all, is the inconsistency of legal reform, extremes in modern judicial practice. Changes in the Code of Criminal Procedure and modern judicial reform in today's law enforcement practice cause a significant increase in the number of people who went unpunished; therefore, they are a source of large-scale criminal infection of the society.

It is also known that juvenile delinquency is caused by various reasons, both social and psychological. They are not considered separately, because they are interdependent, in particular: age psychological characteristics that specify the individual characteristics of the formation of each young person, causing behavioral trends that, «meeting» with social characteristics, become the basis of crime. After all, the developed tendency of adolescents to risk, the desire to get thrills can also cause criminal behavior, provided that the child gets into a corresponding negative environment. Since social, sociopedagogical and psychological aspects are important factors in the occurrence of criminal acts, they must be taken into account in the regulation of behavioral deviations.

One of the reasons for the formation of a tendency to criminal behavior is the lack of proper social and legal protection of minors: drawbacks in the work of law enforcement agencies, insufficient and untimely response to illegal acts and further prevention. Therefore, the crime rate in some sense is a reflection of the current state of legality in our country. At the same time, at the present stage, great hopes are placed on the newly created juvenile justice units, which have replaced the juvenile criminal police.

Thus, objective and subjective factors are interrelated, especially at the practical level. For example, a teenager with disharmonious development and weakened personal abilities is more vulnerable and should be the object of special attention from society and the state. Therefore, the task of preventing criminal behavior is not realized only through the impact on a particular individual, but also through the appropriate social and legal ensuring of the development of children.

A detailed analysis of the current criminal situation among minors has determined the expediency of in-depth, complex development of solutions to the specified problem. The difficulty of its solution is caused by the special complexity of the object of study. In our opinion, the problem is also that the efforts of social workers have little effect on criminal law statistics. 
Analysis of the psychological and pedagogical literature allowed us to conclude that this issue was given considerable attention by scientists: N. Apetyk, R. Blaguta, O. Bodnarchuk, T. Vakulych, N. Klishevych, L. Sokhan, T. Tytarenko, G. Halashand others.

From the analysis of the scientific literature, it follows that adolescence is full of rapid biological changes, exacerbation of contradictions, insecurity and the desire to prove that they are adults, which leads to the formation of feelings of vulnerability, openness to negative external factors. In particular, N. Apetyk considers the connection of delinquency with the individual psychological and age characteristics of the adolescent [1]. R. Blaguta investigates the influence of ways of organizing life in the youth environment on behavioral deviations, the influence of school upbringing, etc. [2].

Detailed psychological analysis of factors and mechanisms of deviance in the youth environment occurs in the works of O. Bodnarchuk and T. Vakulych [3].

A detailed analysis of the forms and methods of socio-pedagogical prevention of behavioral deviations in the youth environment is outlined in the work of N. Klishevych [4].

Thus, the relevance of the problem, insufficient theoretical development is aimed at studying the possibilities of combining criminal law and social aspects to solve the problem of crime in the youth environment.

\section{Research Objective Methodology and Data}

The purpose of the article is to analyze the theoretical aspects of the problem and experimentally test the predisposition of adolescents to criminal behavior for preventive activities in the youth environment.

It should be noted that the analysis of the regulation of behavioral deviations has significant achievements in the modern scientific field, which leads to a logical analysis of scientific research in the field of pedagogy, psychology and jurisprudence; logical-structural analysis - to substantiate the theoretical and methodological foundations of this problem; empirical: (questionnaire, conversation, testing, diagnosis) - to establish the level of predisposition to behavioral deviations in the youth environment.

\section{RESUlTS AND DISCUSSION}

In order to identify the predisposition of adolescents to criminal behavior, we conducted a study involving 56 respondents (31 males and 25 females), students of grades 7-8, who are registered in the juvenile prevention of DPD.

The methods chosen for the study were: "Diagnosis of the tendency to overcome social norms and rules (Yu.A. Kleiberg)", "Methods of diagnosing the tendency to deviant behavior (A.N. Orel)", "Diagnosis of hostility (according to the Cook-Medley scale) ", "Obozov-Shchokin test to determine the degree of determination", "A. Bass-A. Dark diagnosis of indicators and forms of aggression".

Diagnosis of the tendency to overcome social norms and rules (Yu.A. Kleiberg) gave a possibility to measure the readiness of adolescents to implement various types of deviant behavior. Methods of diagnosing the tendency to deviant behavior (A.N. Orel) helped to measure the readiness of adolescents for inappropriate behavior. With the help of the method Diagnosis of hostility (according to the Cook-Medley scale) we managed to determine the tendency of adolescents to show hostility. The degree of determination in each respondent was determined by Obozov-Shchokin test. In order to determine the degree of aggression and the probability of directing destructive actions on ourselves, we used A. Bass-A. Dark diagnosis of indicators and forms of aggression. Therefore, in order to identify the factors that violate the vital competence of adolescents and lead to criminal behavior in teenagers, we have chosen the above methods.

After conducting a diagnosis of the tendency to overcome social norms and rules (Yu.A. Kleiberg), we obtained results that indicate a violation of social and socio-role competence. 
Thus, $82.1 \%$ of the respondents have a high level of predisposition to overcome social norms and rules; $18,9 \%$ - the average level of predisposition to overcome social norms and rules.

Analysis of the results of the methods of diagnosing the tendency to deviant behavior (A.N. Orel) gave the following indicators:

1) on a scale for attitudes towards social desirability: $33.1 \%$ have a moderate tendency to give socially desirable answers; $24.7 \%$ - showed tendencies to pretend to strictly adhere to even insignificant social norms, showed a deliberate desire to show themselves in a better light; $42.2 \%$ - high vigilance of the respondent in relation to the psycho-diagnostic situation and the questionable reliability of the results.

2) on the scale of predisposition to overcome norms and rules: $55.3 \%$ - testified to the exceptional severity of nonconformist tendencies, the manifestation of negativity, which casts doubt on the reliability of test results on this scale; $44.7 \%$ - testified to the conformist attitudes of the respondent, the tendency to follow the generally accepted norms of behavior of adolescents.

3) on the scale of predisposition to addictive behavior: $98.1 \%$ of respondents showed a tendency to deviate from reality by changing their mental state; $1.9 \%$ - vagueness of the above trends.

4) on the scale of predisposition to self-destructive behavior: $96.1 \%$ - indicate a lack of readiness to implement self-destructive behavior; $3.9 \%$ - showed doubts about the reliability of the survey results.

5 ) on the scale of predisposition to aggression and violence $-91.2 \%$ confirmed the presence of aggressive tendencies; $8.8 \%$ - confirmed the aggressive orientation of the individual in relationships with other people, the tendency to solve problems through violence, the tendency to use the humiliation of a communication partner as a means of stabilizing self-esteem.

6) on the scale of volitional control of emotional reactions: in $98.2 \%$ we observed a weakness of volitional control of the emotional sphere, the reluctance or inability to control the behavioral manifestations of emotional reactions; in $1.8 \%$ - the vagueness of these tendencies, the rigid self-control of any behavioral emotional reactions, sensory urges.

7) on the scale of predisposition to delinquent behavior: $96.2 \%$ - demonstrated the presence of delinquent tendencies and a low level of social control; $3.8 \%$ - high willingness to implement delinquent behavior.

In order to determine the predisposition of adolescents to hostility, we used the diagnosis of hostility according to the Cook-Medley scale, and obtained the following results:

1) on the scale of measurement, the level of cynicism of adolescents: $39.4 \%$ - the average rate with a tendency to high; $22.3 \%$ - the average rate with a tendency to low; $9.6 \%$ - the high rate.

2) on the scale of aggression: $55.3 \%$ - the average rate with a tendency to high; $44.7 \%$ - the average rate with a tendency to low.

3) on the scale of hostility: $57.2 \%$ - the high rate; $42.8 \%$ - the average rate with a tendency to high.

Thus, the analysis of the results shows that most adolescents who are registered in the juvenile prevention department have a violation of life skills, which leads to the formation of deviant behavior and is accompanied by a high level of aggression, hostility and cynicism.

Next, we conducted the Obozov-Shchokin test to determine the degree of determination, which aimed to actually determine the level of determination of the respondents.

The test results showed that $49.5 \%$ of respondents belong to the type of people who make decisions very carefully; $26.4 \%$ of respondents are characterized as quite determined people; $24.1 \%$ of adolescents are very determined people.

In this situation, in order to prevent deviant behavior, it is necessary to work on the development of spiritual competence of adolescents, because according to the test $49.5 \%$ of adolescents make decisions very carefully, so we can achieve effective results.

In order to detect physical, direct, non-verbal aggression, irritability, negativism, resentment, suspicion, guilt - we conducted the «A. Bass-A. Dark diagnosis of indicators and forms of aggression».

The results of the study showed the following: adolescents who show: physical aggression is $5.4 \%$; indirect aggression - $6.7 \%$; verbal aggression - $12.3 \%$; irritability is characteristic of $24.9 \%$ of respondents; negativism is characteristic of $10.2 \%$ of respondents; resentment - $23.1 \%$; suspicion is 
observed in $14.3 \%$ of imprisoned adolescents; guilt is observed only in $3.1 \%$ of adolescents under study (fig. 1).

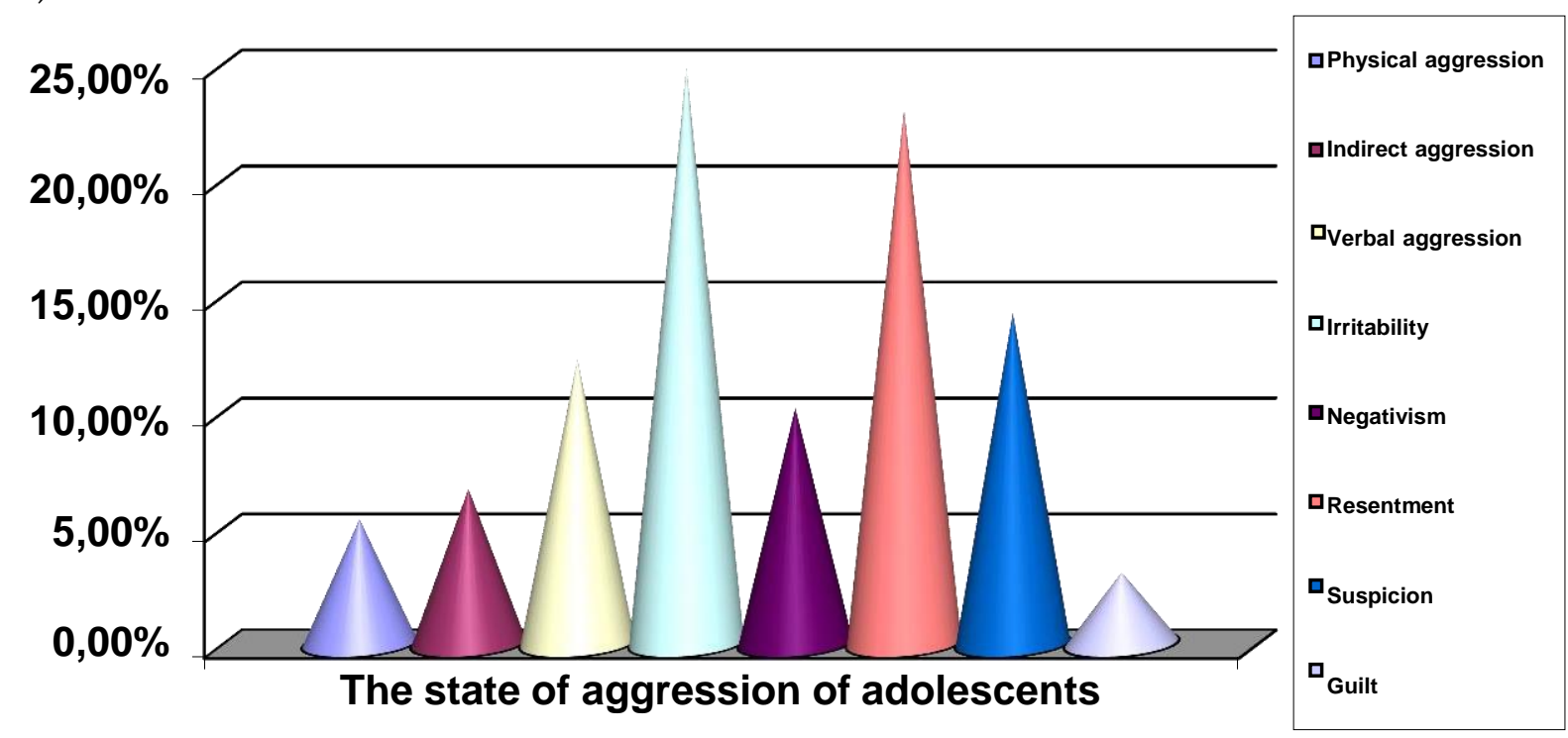

Fig. 1. Diagram of determining the state of aggression of adolescents.

Therefore, in order to identify the causes of various forms of aggression and other signs of criminal behavior according to this diagnosis, when working with adolescents attention should be paid to the state of their cognitive, emotional and spiritual competencies. Because $80-90 \%$ of the surveyed adolescents showed a high level of predisposition to delinquent behavior and such manifestations of behavioral disorders indicate a violation of the above-mentioned competencies of adolescents, which constitute criminal behavior of teenagers.

Analysis of the results of the study also showed that adolescents with impaired life skills are characterized by:

- inability to maintain a partner position in communication or "on equal terms";

- a high level of aggression, suspicion, resentment, irritability and negativism is observed;

- such children have a low level of guilt;

- all respondents show an increased level of anxiety, inability to predict the consequences of their own actions and to logical generalization;

- they have a low level of sociability, poorly understand or simply refuse to understand the requirements of society;

- they are characterized by choleric and sanguine types of temperament;

- low intellectual level;

- lack of parental control, guardianship and communication;

- use of alcohol and other psychotropic substances.

Thus, based on the above, it can be claimed that criminal behavior is a factor in the violation of such aspects of life competence in the studied adolescents as communicative, intellectual and sociopsychological.

The basic and main direction of combating juvenile delinquency is its prevention. Hence, the key social task of social workers, social educators, modern law enforcement agencies, the priority of their various activities is the regulation of behavioral deviations and crimes in general and in the youth environment in particular.

An analysis of sociological research conducted in recent years in Ukraine has convincingly shown that crime among young people is inextricably linked with the shortcomings of the educational process, non-employment in free time, poor organization of leisure, especially by the place of residence, low cultural level, limited needs of adolescents. 
Scientists emphasize the necessity to consider special criminological, namely individual prevention of juvenile delinquency, which outlines a wide range of different in nature measures naturally aimed at regulating crimes and offenses, in particular, at identifying and eliminating factors and conditions that cause criminal behavior of minors.

In the modern scientific literature, individual preventions are considered to be the impact on adolescents who may commit crimes and on their social environment. This type of activity is a purposeful work with a specific adolescent and his close people.

Accordingly, the objects of individual prevention are adolescents, whose behavior and lifestyle indicate the possibility of committing real crimes. Views, motives, system of value orientations of the adolescent become the basis for the implementation of preventive influence on him only if these views, motives, orientations are manifested in the anti-social behavior of the adolescent.

Considering the mechanism of juvenile criminal behavior, individual prevention should be directed at him and his negative traits, the environment that shapes him, as well as conditions, circumstances and situations that promote or facilitatecommitting of criminally punishable acts by minors. Thus, according to researchers, individual prevention of criminal behavior includes the activities of governmental and non-governmental bodies, organizations and their representatives, which identify adolescents who can be expected to commit crimes, and the implementation of positive and corrective influence on them and their microenvironment [5, p. 18].

Accordingly, measures of individual prevention in relation to the adolescent play the role of a social tool that neutralizes or eliminates the internal negative traits of the adolescent and their behavior. When the impact is directed to the social microenvironment, the external negative factors of the material and spiritual spheres that deform the adolescent are neutralized or eliminated.

In a detailed form, the objects of individual prevention of juvenile delinquency are: anti-social behavior and lifestyle of adolescents who may commit a crime; criminologically significant characteristics of the adolescent, which characterize the deformation of their behavior; criminologically significant psychophysiological features: sane abnormalities in the psychics, deviations in sexual behavior, etc.; immediate conditions of unfavorable formation and life of the adolescent: family, environment; elements of the negative life situation of the adolescent, which are objectively criminogenic in nature and have existed for a long time [6].

The purpose of individual prevention is a positive correction of the adolescent's behavior, which leads to changes in his behavior from anti-social to law-abiding.

Achieving this goal requires specific tasks: identifying adolescents whose behavior indicates a real possibility of committing crimes; identification of sources of negative impact on them; prediction of individual behavior; planning of measures of individual prevention with the adolescent; positive control effect on the adolescent.

The tasks facing the regulation of behavioral deviations include two more, which are regulated by legal acts, and their implementation is carried out in relation to clearly defined categories of individuals, as the implementation of these tasks affects the sphere of personal interests and even freedoms of citizens. We emphasize the peculiarities of registration of an adolescent and the control over their behavior and lifestyle.

In the process of studying the adolescent as an object of preventive action, we analyze:

1) criminal or other illegal behavior of adolescents;

2) circumstances that cause and stipulate criminal or other illegal behavior of adolescents;

3) socio-demographic characteristics of adolescents;

4) individual psychological features, in particular the level of intelligence of the adolescent;

5) the presence of predispositions to the antisocial character of the adolescent;

6) signs of an adolescent 's criminal experience;

7) living conditions and close people of the adolescent.

For the comprehensive study of the adolescent, such methods are used:

- familiarization with the documents;

- analysis of the adolescent's actions; 
- conversations with people who know the adolescent well;

- study of the medical and other documents, the environment of the adolescent.

In the process of studying the adolescent the prediction of their individual criminal behavior or individual prediction is carried out. This is quite a difficult task, and it is solved on the basis of an assessment of the whole set of internal and external factors that caused this behavior of the adolescent. Individual prediction can only be reliable, outlining only the possible criminal behavior of the adolescent. Therefore, the effectiveness of crime prevention measures depends on the accuracy and completeness of information about the adolescent.

Thus, individual prevention and prediction of criminal behavior of adolescents is the same process. The prevention itself implies a constant in-depth study of the adolescent's personality, their behavior, relationships with others, intentions of behavior. On the basis of the received information and the prediction correction of the plan of individual work with the adolescent prone to criminal behavior is carried out.

An important task for juvenile prevention workers is to address the issue of taking an adolescent for preventive registration. This decision is based on strict compliance with departmental normative regulations, namely orders, instructions.

Taking an adolescent for such a registration necessitates the use of intensive measures of influence, which are carried out on the basis of plans for individual work with them.

Planning aims at organization a complex and multifaceted process of preventive influence, making it purposeful, identifying the most rational means of working with this adolescent, choosing such tactical forms, methods and techniques that provide effective achievement of the goal of preventing criminal behavior of an adolescent in a particular situation.

According to theorists and practitioners, the use of methods of individual prevention of criminal behavior of adolescents requires a significant long-term and systematic impact. At the same time, it is necessary to apply the whole arsenal of methods, as well as all the forces and means of influencing the adolescent, which correspond to the democratic principles of attitude to the adolescent [7, p. 106-107].

Methods of individual influence include: providing of help; persuasion; enforcement.

The method of persuasion is understood as a set of educational, explanatory measures taken to change the antisocial orientation of the adolescent to consolidate their positive social orientation. Persuasion is used to present or neutralize the main anti-social orientations that can lead to the commission of crimes by an adolescent.

The method of persuasion is implemented using the forms:

- individual and collective conversations;

- discussion of the adolescent's behavior in the classroom;

- establishment of guardianship and patronage over them.

Psychological methods of influencing the intelligence, feelings and will of the adolescent are the basis of the process of implementation of methods of persuasion. In practical application, conversations are effective. The following types of conversations are used for individual prevention of criminal behavior of adolescents: introductory; preventive; educational.

The criminal law measures of individual prevention of criminal behavior include such measures as bringing to justice persons under the articles of the Criminal Code with the so-called "double prevention" (threat of murder; manufacture, storage and sale of weapons, etc.).

Individual prevention of criminal behavior of adolescents has a significant specificity in the absence of information about adolescents who have committed unsolved crimes and the perpetrators continue to commit criminal activities. The source of this information regarding probable adolescents of preventive influence can be:

- books and journals of accounting of crimes and incidents (BACI);

- criminal cases, materials on refusal to initiate criminal cases and on its suspension and closure;

- materials on administrative and other offenses of adolescents;

- statements of citizens; 
- informing of the media.

The use of this information allows you to approximately outline the range of adolescents with whom it is necessary to intensify individual prevention activities.

\section{CONCLUSIONS}

Accordingly, summarizing the above, we can say that the essence of the regulation of behavioral deviations in the youth environment is to prevent adverse living conditions of adolescents, namely to eliminate the factors that can cause certain negative consequences. This indicates that prevention should be carried out in the form of planned actions aimed mainly at achieving the desired result and at the same time at preventing possible negative events.

It is studied that the prevention of crime in the youth environment is based on precise principles, which include: individual approach, comprehensive legality, humanism and timeliness, which are aimed at implementing a system of appropriate measures to identify and eliminate the causes and conditions that contribute to committing crimes and influence adolescents who are prone to illegal actions.

Educational work related to the regulation of behavioral deviations in the youth environment should be based on legal education. At the same time, due to the unpreparedness of specialists for the outlined work, the lack of the necessary literature the designated does not meet modern needs. Therefore, the outlined education is mainly reduced to acquainting adolescents with the key positions of the Criminal Code. At the same time, other areas of law that play no less a role in the lives of adolescents are ignored.

At the same time, the work of a social worker with adolescents prone to criminal behavior consists in establishment on relationships, joint activities, constant attention to adolescents, control, analysis of your attitude to a particular adolescent, including personal and individual approach.

The social worker must have scientific and pedagogical knowledge about the means of influencing adolescents, their psychological peculiarities, tact, knowledge of professional ethics, organizational skills, knowledge of the forms, methods, individual and personal approach to difficult adolescents.

The current nature of the general patterns of the process of social rehabilitation of adolescents prone to criminal behavior includes the following principles: the principle of integration; the principle of systematics; the principle of an objective position in interaction with the youth environment; principle of activity; the principle of stability; the principle of positive emotional environment of adolescents.

Using detailed information about adolescents prone to criminal behavior, the social worker should apply pedagogical technologies, which consist in motivated activities that ensure the effectiveness and reliability of the results of the regulation of behavioral deviations in the youth environment.

\section{REFERENCES}

[1] Apetyk N.M. Unformed moral self-regulation as a determinant of occurrence of deviant behavior of adolescents. Bulletin of Kharkiv University. Psychology series, (2010), 9-12. (in Ukrainian)

[2] Blaguta R.I. Prevention of juvenile delinquency: psychological and legal aspects: a monograph. Lviv, 2008. (in Ukrainian)

[3] Bodnarchuk O. Vakulych T. Psychology of deviant behavior. Kyiv, 2008. (in Ukrainian)

[4] Klishevych N.A. Forms of socio-pedagogical work with adolescents with delinquent behavior in various social institutions. Pedagogical education: theory and practice. Psychology. Pedagogy, 19 (2013), 8083. (in Ukrainian)

[5] Zuzyak M. Factors of criminal behavior in adolescence. Social work: theory and practice, 2 (2018), 18-22. (in Ukrainian) 
[6] Zobenko N. Interaction of school psychologist and social educator in crime prevention among young people. Kyiv, 2004. (in Ukrainian)

[7] Vasiliev Yu., Tikhonenko S. The costs of deformed socialization of adolescents. Moscow, 2011. (in Russian)

Address: Roksoliana Zozuliak-Sluchyk, Vasyl Stefanyk Precarpathian National University, 57 ShevchenkoSt., Ivano-Frankivsk 76018, Ukraine.

E-mail: zozulyak_roksolyana@ukr.net.

Received: 03.02.2021; revised: 21.03.2021.

Зозуляк-Случик Роксоляна. Регуляція поведінкових девіацій у молодіжному середовищі. Журнал Прикарпатського університету імені Василя Стефаника, 8 (1) (2021), 165-173.

Проблема регуляції поведінокових девіацій у молодіжному середовищі привертає увагу багатьох дослідників різних галузей науки. Під регуляцією поведінкових девіацій розуміють профілактиу несприятливих умов життедіяльності підлітків, тобто усунення чинників, здатних викликати ті або інші негативні наслідки. У статті розкрито та проаналізовано важливі чинники, які зумовлюють здочинну поведінку піддітків. Зокрема виокремлено такі, як: безцензурна пропаганда негативних стилів поведінки, що провокують підлітків до наслідування “героїв" $з$ кривавою та насильницькою поведінкою; вплив сімей, у яких дітям ще з дошкільного віку приділяють мало уваги, закривають очі на їх погану поведінку, безвідповідальне ставлення до оточуючого світу та оточення, заохочують примхи; непослідовність правової реформи, крайнощі у сучасній судовій практиці. Також подано резудьтати дослідження схидьності до здочинної поведінки піддітків. Для дослідження обрано методики: “Діагностика схильності до подолання соціальних норм і правил (Ю.А. Клейберг)", “Методика діагностики схидьності до девіантної поведінки (А.Н. Орел)”, “Діагностика ворожості (за шкалою Кука-Медлей)”, “Тест Обозова-Щокіна для визначення ступеня рішучості”, “Діагностика показників та форм прояву агресії А. Басса-А. Дарки". Детально розглянуто такий вид соціальної регуляції поведінкових девіацій як індивідуальне попередження злочинності підлітків. Суть його полягає в цілеспрямованій роботі 3 конкретним підлітком та його найбдижчим оточенням. Здійснювати даний вид комплексно покликані соціальні працівники, соціальні педагоги та сучасні правоохоронні органи. Індивідуальне попередження направляється на підлітка та його негативні риси, середовище, яке його формуе, а також умови, обставини та ситуації, що сприяють чи полегшують вчинення здочинів неповнолітнім.

Ключові слова: регуляція поведінкових девіацій, молодіжне середовище, підліток, профілактика, попередження, девіантна поведінка, здочин. 